\title{
ARCHAEOLOGY VS. SCIENCE Or taking knowledge-based communication seriously?
}

\section{Christopher Prescott}

Archaeologists have embraced novel results, and built on some of the new data, not always understanding the theoretical and methodological bases on which these results were founded; some of these foundations have since been shown to be unsteady. Premature adoption of poorly evaluated analytical techniques and their preliminary results have given archaeology a decade or more of spectacular claims and attendant rebuttals, creating an uneasy atmosphere (Dincauze 2000:3).

Lidén and Eriksson's article is concerned with one of the important debates in contemporary archaeology. Interdisciplinary collaboration and the relationship between archaeology, technology and science are familiar themes (e.g. Butzer 1982; Dincauze 2000), but the impact of science on contemporary archaeology makes a re-examination of these issues imperative. Though science is transforming archaeological interpretation and practices, Lidén and Eriksson maintain that there is not a sufficiently extensive and authentic commitment in the collaboration along the science-archaeology intersection, that scientists often do not take the archaeological side of the equation seriously, and that archaeologists do not sufficiently appreciate basic concepts, methodological premises and source-critical latitudes when working with scientific data. This generates scepticism, "filters", towards results, in part because they are politically or empirically at odds with preconceived empirical expectations or political-theoretical prejudices in archaeology. 
The methodological, theoretical, interpretative and sociological implications of the ongoing archaeometrically driven transformation seem to be more extensive than Lidén and Eriksson suggest (Prescott 20I3). Though I find their critique pertinent, I believe the practices and positions they outline are generated from deeper structure and agendas i.e. related to theory (interpretative, ontological and epistemological), politics, methodology and sociology. In light of the unfolding quantum leap in knowledge production it is imperative to develop a more seamless cross-disciplinary collaboration. Crucial to cultivating such practices are knowledge and communication.

The co-history of archaeology and science in the Nordic countries runs deep. Biological, physical and geological samples are routinely collected and analysed. There are some laboratories dedicated to archaeoscience. Still, I would maintain that collaboration is often random, mechanical and superficial. Most archaeologists routinely exercise source criticism when it comes to archaeology. When faced with science, most archaeologists hold a stereotyped version of science as hard and objective, leading to arbitrary acceptance or rejection of claims. When scientists make superficial use of archaeology, the result is reinforced circular reasoning (e.g. in the use of palaeo-ecological data). Lidén and Eriksson aptly mention radiocarbon's history. After an initial technological breakthrough and ensuing application of the methodology, it became clear that there were mistaken premises in its application (e.g. variable radiation, global distributions of isotopes, fractionation, statistics and measurement noise). Many of these factors could not be corrected theoretically, but only through long-drawn-out processes such as refining calibration. "Faced with these aspects it is not surprising that some archaeologist throw up their hands in despair" (Aitken 1999:99). Others stood dogmatically by the method's results. In retrospect, taking onboard the physics and chemistry involved would have been a more profitable strategy - but most archaeologists did not have the training to do so, and it would have challenged deep-seated notions of science.

One of the heated debates about the humanities and sciences was initiated in the wake of C. P. Snow's 1959 Rede Lecture, where he contended that the lack of common references between the two areas of study had created "two cultures", with a detrimental impairment in knowledge production and application. Though Snow critiqued both sides of the divide, e.g. contending that most scientists never read Dickens or Shakespeare, he maintained that British society had prioritized the arts and humanities since the I $800 \mathrm{~s}$, and that humanists were virtually illiterate when it came to the sciences. The second law of thermodynamics is his often cited example, and he argued "I now believe that if I had asked 
an even simpler question - such as, What do you mean by Mass, or acceleration, which is the scientific equivalent of saying, Can you read? not more than one in ten of the highly educated would have felt that I was speaking the same language. So the great edifice of modern physics goes up, and the majority of the cleverest people in the western world have about as much insight into it as their Neolithic ancestors would have had" (Snow I959:15).

When confronted with scientific prose, archaeologists tend to attribute the differences between humanities and sciences to an epistemological chasm. However, according to Dena Dincauze (2000:2I), "[w]ithin the historical disciplines, the mode of discourse and the tone of reporting in the natural sciences may be less qualified, less hesitant, than that of the social sciences. That is tradition and style; it is not a reflection of a tighter grasp on 'truth'." This is a bit at odds with the perceptions generated by theoretical discourse. Increasingly from Montelius (e.g. 1900) to processual archaeology, stereotyped science was held as an ideal for archaeology. Though later discredited (Gibbon 1989), even at the start these perceptions were hardly accurate descriptions of the sciences. Ironically (?), post-modern archaeology reproduced this view of science, maybe because it was useful as a discursive straw man to support relativist epistemology, argument structures and "humanist" ontologies? The more vocal contenders in our contemporary theoretical debate do not provide platforms for integrating science and archaeology; materiality and symmetrical archaeology uphold post-modernism's scale and conceptions, while neo-evolutionary trends echo the r97os.

Lidén and Eriksson are right in pointing out that results in archaeoscience challenge pet positions in Northern European archaeology concerning historicity, identity, boundaries, movements, migrations, conflicts and adaptations. In light of my own work concerning the third millennium BC (Prescott \& Walderhaug 1995; Prescott \& Glørstad 20I2), it is no surprise I am pleased with results from isotope analyses, aDNA and radiocarbon. I am, however, perplexed by the fact that old attitudes to science in a way are reproduced in that biochemistry was necessary for many archaeologists to accept what archaeological data (e.g. Anthony 2008; Kristiansen 199I), anthropological perspectives (Barth I969, I990) and neo-geographical theory (Anthony I990) made obvious. However, of greater concern here is the pendulum effect in theory and interpretation. In my opinion there is reason for concern in a lack of anthropological and historical underpinnings when isotope data or DNA data are mechanically or empiristically "interpreted" with unqualified concepts of migration and movements, identity or conflict, echoing the I920s cultural history. It is also pressing to develop the methodological 
and theoretical deliberations in simply interpreting science data. I am probably more concerned than Lidén and Eriksson with superficial contextualization and under-theorizing of science-based results, whether among archaeologists or scientists.

Though archaeology has a strong autonomous identity, it is inherently a borrower discipline. Cross-disciplinary work is essential, but difficult. Conflicts arise, or the need for collaboration is disregarded. Such practices, like other conflicts in archaeology, may be driven by personal chemistry, competition and disciplinary rivalry. More importantly, interdisciplinary collaboration is complicated by rhetoric, practices and concepts that evolve within disciplines, into which practitioners are socialized through training. Specialists from other disciplinary communities readily run afoul along the interface, with clashes and misunderstandings ensuing. When using the results of another discipline "[w]e seem perilously close to that characteristic failing of interdisciplinary study - an enterprise which often seems to merit definition as the process by which the unknowns of one's own subject matter are multiplied by the uncertainties of some other science..." (Sahlins I974:5I). The response to all of the above is collaboration, but it is still "crucial for researchers to command the basic theory and assumptions of other special fields and disciplines, in order to evaluate claims for new methods, applications and results" (Dincauze 2000:4). Knowledge remains key. With increasing publication and specialization, the mastering of such knowledge is inherently difficult. The situation is exacerbated, in my experience, by attitudes among students and professionals in archaeology that mirror general societal developments. Science and technology have been regarded with scepticism, there has been an emphasis on humanities in the school system, fewer programmes span science and the humanities, and the gulf widens. Concurrently, in my opinion, science and technology have lost interest in much of post-modern humanities. It is interesting that 75 years ago, C. P. Snow blamed the educational system for the prejudiced state of mutual ignorance between scientists and humanists.

I agree with the thrust in Lidén and Eriksson's article, but believe the present revolution in archaeology and science will even more profoundly impact cultural-historical data, interpretative context, methodology and theory (from source criticism to epistemology, and in time fundamental concepts and values). Though I'm a staunch believer in what motivated and enlightened individuals can accomplish, I think that the theoretical, sociological and political issues that hinder an authentic integration of archaeology and science have deeper roots than Lidén and Eriksson argue. It is therefore probably no surprise that I do not believe that a call for a change in attitude is sufficient. In a Norwegian context I have advo- 
cated awareness of the organizational challenges and the need for longterm investment. However, like Lidén and Eriksson, I would start with communication. Communication is based on knowledge, and knowledge is based on the insights training engenders in theory, assumptions, methods, applications, validity and relevance. If this holds true, a revamping of university programmes in archaeology is perhaps a starting point? The science competences that archaeologists will have to possess to be qualified partners in knowledge production in the coming decade should make this a priority.

Christopher Prescott University of Oslo, IAKH

$\mathrm{Pb}$ IOI9 O3I 5 Oslo Norway

\section{REFERENCES}

Aitken, M. J. 1990. Science-based Dating in Archaeology. Essex: Longman.

Anthony, D. W. 1990. Migration in Archeology: The Baby and the Bathwater. American Anthropologist. Vol. 92/I. Pp. 896-914.

Anthony, D. W. 2007. The Horse, the Wheel, and Language: How Bronze-Age Riders from the Eurasian Steppes Shaped the Modern World. Princeton: Princeton University Press.

Barth, F. 1990. The Guru and the Conjurer: Transactions in Knowledge and the Shaping of Culture in Southeast Asia and Melanesia. Man 25. Pp. 640-653.

Barth, F. 2002. An Anthropology of Knowledge. Current Anthropology 43/r. Pp. I-I8.

Butzer, K. W. 1982. Archaeology as Human Ecology. Cambridge: Cambridge University Press.

Dincauze, D. F. 2000. Environmental Archaeology: Principles and Practice. Cambridge: Cambridge University Press.

Gibbon, G. 1989. Explanation in Archaeology. Oxford: Basil Blackwell.

Kristiansen, K. I991. Prehistoric Migrations - the Case of the Single Grave and Corded Ware Cultures. Journal of Danish Archaeology 8/I989. Pp. I37-I5I.

Montelius, O. I900. Typologien eller utvecklingslären tillempad på det menneskeliga arbetet. Stockholm: Norstedt.

Prescott, C. 20I3. Utfordrer archaeo-science norsk arkeologi? Primitive tider I5. Pp. $47-58$.

Prescott, C. \& Walderhaug, E. I995. The Last Frontier? Processes of Indo-Europeanization in Northern Europe. The Norwegian Case. The Journal of Indo-European Studies 3 \& 4. Pp. 257-280.

Prescott, C. \& Glørstad, H. 20I2. Introduction: Becoming European. In: Prescott, C. \& Glørstad, H. (Eds). Becoming European: The Transformation of Third Millennium Northern and Western Europe. Pp. I-I I. Oxford: Oxbow Books. 
Sahlins, M. 1974. Stone Age Economics. London: Tavistock Publications.

Snow, C. P. 1959. The Two Cultures and the Scientific Revolution. The Rede Lecture. Cambridge: Cambridge University Press. 